\title{
COMPARISON OF FREE-RANGE, BARN AND CAGED HENS' EGGS COMMERCIALLY AVAILABLE IN LATVIA
}

\author{
Asnate Kirse-Ozolina \\ Department of Food Technology, Faculty of Food Technology, Latvia University of Life Sciences and Technologies, Rigas iela 22, \\ Jelgava, Latvia, e-mail: asnate.kirse@llu.lv
}

\begin{abstract}
Consumers often consider free-range eggs to be superior to eggs from caged hens. The aim of the study was to identify whether different hen housing systems had an influence on egg quality in Latvia. Free-range, barn and caged hens' eggs commercially available in Latvia were obtained at the production facility of Balticovo JSC. The average sample of forty eggs of each type were analysed at the laboratories of Faculty of Food Technology, Latvia University of Life Sciences and Technologies and J.S. Hamilton Baltic JSC. Such parameters as nutritional and energy value, fatty acid profile, cholesterol, vitamins A, E, D, B $1, B_{2}, B_{3}, B_{6}, B_{7}, B_{9}, B_{12}$, minerals Na, K, $\mathrm{Ca}, \mathrm{Mg}, \mathrm{Fe}, \mathrm{Cu}, \mathrm{Zn}, \mathrm{Se}, \mathrm{I}, \mathrm{P}, \mathrm{Cl}$, heavy metals $\mathrm{Pb}, \mathrm{Cd}$ and microbiological quality were assessed. Comparison to reference intakes and possible indication of nutrient claims was evaluated according to published nutrient recommendations and EU regulations. The results show that depending on egg type it is possible to use such nutrient claims as "high protein", "high omega-3 fatty acids", "high monounsaturated fat", "source of vitamin A", "source of vitamin E", "high vitamin B2", "high selenium", "source of phosphorus", "source of vitamin D" and "source of iodine". All egg samples were microbiologically safe and did not contain heavy metals. Nutrient content varied significantly within some of the parameters in eggs commercially available in Latvia $(\mathrm{p}<0.05)$; however, whether consumers choose free-range, barn and caged hens' eggs has an insignificant effect on their diet, based on daily egg consumption per capita.
\end{abstract}

Keywords: egg quality, nutritional value, population reference intakes

\section{Introduction}

Eggs are an excellent source of various macro- and micronutrients - easily digestible protein, including all essential amino acids, unsaturated fat, lecithin, fatsoluble and water-soluble vitamins, and minerals (Miranda et al., 2015; Kralik, Kralik, 2017). There are several factors which influence nutritional quality of hen eggs such as breed and age of hen, feed composition and nutrient density, in addition to the rearing system (Küçükyılmaz et al., 2012).

Depending on the hen housing system, in the EU eggs are coded using numbers 0-3 (Commission Regulation (EC) No 589/2008): 0 - organic eggs, 1 - free-range eggs, 2 - barn eggs, 3 - eggs from caged hens.

Scientific literature notes that there can be noticeable differences in some qualitative parameters between eggs from conventional and organic rearing systems (Küçükyılmaz et al., 2012). However, further research is needed in controlled settings, as egg quality is more directly associated with hen nutrition than hen housing within the conventional system (Karcher et al., 2015). Several scientists (Karsten et al., 2010; Anderson, 2011) point out that free-range eggs contain more vitamin $\mathrm{E}$ and long chain $\omega 3$ fatty acids, have a significantly lower $\omega 6: \omega 3$ ratio, whereas eggs from caged hens have a lower fat content and less mono- and polyunsaturated fats than free-range eggs and barn eggs. Recent data has shown a significant effect of hen diet with regards to $\omega 3$ fatty acid content in eggs (Coorey et al., 2015).

A research from 2012 pointed out that a significant part of consumers believe that organic and free-range eggs are more nutritious and tastier than conventional eggs (Küçükyılmaz et al., 2012), yet there is no consistent evidence in scientific literature. Whereas, data from 2008 indicated that consumers are mainly interested in egg freshness and price, showing little interest in layer rearing system (Sokołowicz et al., 2008).
As literature data demonstrates variable results on egg qualitative parameters and such research has not been carried out before, the aim of the study was to identify whether different hen housing systems had an influence on egg quality in Latvia.

\section{Materials and Methods}

Materials

Free-range, barn and caged hens' eggs commercially available in Latvia (Table 1) were obtained at the production facility of Balticovo JSC during the beginning of September 2018. Forty eggs of each type were analysed at the laboratories of Faculty of Food Technology, Latvia University of Life Sciences and Technologies and J.S. Hamilton Baltic JSC.

Eggs used for the research

Table 1

\begin{tabular}{lll}
\hline $\begin{array}{l}\text { Sample } \\
\text { code }\end{array}$ & $\begin{array}{c}\text { Farming method } \\
\text { (Commission Regulation } \\
(\text { EC) No 589/2008) }\end{array}$ & $\begin{array}{c}\text { Type of eggs on the } \\
\text { market }\end{array}$ \\
\hline O_11 & Free range eggs & FREE RANGE eggs \\
O_22 & Barn eggs & Farmer - Barn eggs \\
O_33 & Eggs from caged hens & Eggs in boxes \\
\hline
\end{tabular}

\section{Nutritional composition and qualitative parameters}

Nutritional and energy value of eggs was determined according to EU Regulation No 1169/2011. Standard methods were used to assess such nutritional parameters as moisture (PN-A-86509:1994), protein (PB-116 ed. II of 30.06.2014), total fat (PN-A86509:1994), fatty acids (PN-EN ISO 12966-1:2015, PN-EN ISO 12966-2:2011), ash (PN-A-79011-8:1988), sugar (PB-287 ed. Of 27.09.2014) and cholesterol (PB-75/GC ed. I of 20.01.2009); carbohydrates were calculated by difference (FAO, 2003). 
The content of $\mathrm{Na}, \mathrm{K}, \mathrm{Ca}, \mathrm{Mg}, \mathrm{P}, \mathrm{Fe}, \mathrm{Cu}, \mathrm{Zn}$, Se was determined using flame atomic absorption spectrometry according to PB-223/ICP, ed. II of 12.01.2015. Chloride was assessed using potentiometry (PN-EN ISO 5943:2007), whereas iodine content was analysed according to DIN EN 15111:2007-06. Heavy metals were assayed according to PB-68/ICP ed. III of 18.09.2012.

The following methods were used to determine fatsoluble and B-group vitamins in eggs: PB-40/HPLC ed. III of 28.02.2009 for A and E vitamin, PN-EN 12921:2009 for cholecalciferol, PN-EN 14122:2014-07 for thiamine, PN-EN-14152:2014-07 for riboflavin, EN 12652:2009 for niacin, PN-EN 14164:2014-08 for pyridoxine, PB-244 ed. I 10.10.2013 for biotin, PB-372 ed. I 30.11.2015 for folic acid, and PB-328 ed. I 30.11.2015 for cobalamin.

In order to evaluate microbiological quality of eggs from different hen laying systems such parameters as the count of mesophilic aerobic and facultative anaerobic microorganisms (ISO 4833-1:2013) and Enterobacteriaceae (ISO 21528-2:2017) were assessed.

Comparison to reference intakes of vitamins and minerals, and eligibility to nutrient claims

Eligibility to nutrient claims (Table 2) was evaluated according to Regulation (EC) No 1924/2006 with regards to protein, vitamins and minerals, and Regulation (EC) No 116/2010 with regards to fatty acid content and profile.

Table 2

Nutrient claim guidelines for eggs (Regulation (EC) No $1924 / 2006$, No $116 / 2010$, No $1169 / 2011$ )

\begin{tabular}{|c|c|}
\hline Nutrient claim & Explanation \\
\hline high protein & $\begin{array}{l}\text { at least } 20 \% \text { of the energy value of } \\
\text { the food is provided by protein }\end{array}$ \\
\hline $\begin{array}{l}\text { source of [name of } \\
\text { vitamin/s] and/or } \\
\text { [name of mineral/s] }\end{array}$ & $\begin{array}{c}\text { at least } 15 \% \text { of the nutrient reference } \\
\text { values supplied by } 100 \mathrm{~g}\end{array}$ \\
\hline $\begin{array}{l}\text { high [name of } \\
\text { vitamin/s] and/or } \\
\text { [name of mineral/s] }\end{array}$ & $\begin{array}{l}\text { at least twice the value of 'source of } \\
\text { [name of vitamin/s] and/or [name of } \\
\text { mineral/s]' }\end{array}$ \\
\hline $\begin{array}{l}\text { source of omega-3 } \\
\text { fatty acids }\end{array}$ & $\begin{array}{c}\text { at least } 0.3 \mathrm{~g} \text { ALA, or at least } 40 \mathrm{mg} \\
\text { of the sum of EPA and DHA per } \\
100 \mathrm{~g} \text { and per } 100 \mathrm{kcal}\end{array}$ \\
\hline $\begin{array}{l}\text { high omega-3 fatty } \\
\text { acids }\end{array}$ & $\begin{array}{c}\text { at least } 0.6 \mathrm{~g} \text { ALA, or at least } 80 \mathrm{mg} \\
\text { of the sum of EPA and DHA per } \\
100 \mathrm{~g} \text { and per } 100 \mathrm{kcal}\end{array}$ \\
\hline $\begin{array}{l}\text { high } \\
\text { monounsaturated fat }\end{array}$ & $\begin{array}{l}\text { at least } 45 \% \text { of the fatty acids } \\
\text { present in the product derived from } \\
\text { MUFA and MUFA provides more } \\
\text { than } 20 \% \text { of energy of the product }\end{array}$ \\
\hline
\end{tabular}

ALA - $\alpha$-linolenic acid, EPA - eicosapentaenoic acid, DHA - docosahexaenoic acid, MUFA - monounsaturated fatty acids

Comparison of the amount of micronutrients to population reference intakes of vitamins and minerals (incl. coverage (\%) calculation) was carried out based on EU Regulation No 1169/2011 (Annex XIII) and the ordinance No 212 "Recommended allowance of energy and nutrients for Latvian citizens", issued by Ministry of Health of the Republic of Latvia on November 24, 2017 (Table 3). The second document was developed on the basis of the Nordic Nutritional Recommendations (Nordic Council of Ministers, 2012).

Table 3

Vitamin and mineral daily requirements

\begin{tabular}{|c|c|c|}
\hline \multirow{2}{*}{$\begin{array}{l}\text { Vitamin or } \\
\text { mineral }\end{array}$} & \multicolumn{2}{|c|}{ Population reference intake } \\
\hline & $\begin{array}{c}\text { EU Regulation } \\
\text { No } 1169 / 2011 \\
\end{array}$ & $\begin{array}{c}\text { Ordinance } \\
\text { No } 212 \\
\end{array}$ \\
\hline $\mathrm{A}, \mu \mathrm{g}$ & 800.0 & $900 \hat{\jmath}, 700$ 우 \\
\hline $\mathrm{E}, \mathrm{mg}$ & 12.0 & $10 \hat{\jmath}, 8$ q \\
\hline $\mathrm{D}, \mu \mathrm{g}$ & 5.0 & 10 \\
\hline $\mathrm{B}_{1}, \mathrm{mg}$ & 1.1 & $1.4 \hat{\partial}, 1.1$ 우 \\
\hline $\mathrm{B}_{2}, \mathrm{mg}$ & 1.4 & 1.5 \\
\hline $\mathrm{B}_{3}, \mathrm{mg}$ & 16 & n.d. \\
\hline $\mathrm{B}_{6}, \mu \mathrm{g}$ & 1.4 & 1.5 万ิ, 1.3 우 \\
\hline $\mathrm{B}_{12}, \mu \mathrm{g}$ & 2.5 & 2.0 \\
\hline $\mathrm{B}_{9}, \mu \mathrm{g}$ & 200.0 & $300 \AA, 400$ 우 \\
\hline $\mathrm{B}_{7}, \mu \mathrm{g}$ & 50.0 & n.d. \\
\hline $\mathrm{K}, \mathrm{mg}$ & 2000.0 & $3500 \curvearrowright, 3100$ ㅇ \\
\hline $\mathrm{Ca}, \mathrm{mg}$ & 800.0 & 800 \\
\hline $\mathrm{Mg}, \mathrm{mg}$ & 375.0 & $350 \AA, 280$ 우 \\
\hline $\mathrm{P}, \mathrm{mg}$ & 700.0 & 600 \\
\hline $\mathrm{Fe}, \mathrm{mg}$ & 14.0 & $9 \hat{\jmath}, 15$ ㅇ \\
\hline $\mathrm{Cu}, \mu \mathrm{g}$ & 1000.0 & 900 \\
\hline $\mathrm{Zn}, \mathrm{mg}$ & 10.0 & $9 \widehat{\jmath}, 7$ q \\
\hline $\mathrm{Se}, \mu \mathrm{g}$ & 55.0 & $60 \widehat{\partial}, 50$ 우 \\
\hline $\mathrm{I}, \mu \mathrm{g}$ & 150.0 & 200 \\
\hline
\end{tabular}

Data processing

The obtained data was processed with MS Excel v16 software; differences among results were considered significant at $\mathrm{p}<0.05$. One-way ANOVA and Tukey's test were used to analyse the differences within data.

\section{Results and Discussion}

Nutritional composition of eggs from different hen laying systems

The results of nutritional value parameters of eggs (Table 4) from different hen housing systems show that eggs from caged hens (sample O_33) contain 9\% less protein than free-range or barn eggs $(p>0.05)$. Free-range chicken eggs have $10 \%$ less fat $(p>0.05)$, but both free-range and barn eggs contain more cholesterol than caged eggs, respectively $32 \%$ and $64 \%$ more. Eggs from caged hens contain significantly less cholesterol compared to barn eggs $(\mathrm{p}<0.05)$.

The latest literature data shows that dietary cholesterol has minimal effect on blood cholesterol levels in practically healthy individuals (BenitoVicente et al., 2018), thus, content of cholesterol in eggs should not be considered problematic.

The composition of fat was similar within all groups; free-range eggs (sample O_11) showed insignificantly 
lower saturated and monounsaturated fatty acid content ( $p>0.05$ ). With regards to long chain $\omega 3$ fatty acids, especially EPA and DHA, there were no differences among egg samples.

Table 4

Nutritional parameters and energy value of eggs from different hen housing systems per $100 \mathrm{~g}$

\begin{tabular}{llll}
\hline \multirow{2}{*}{ Parameters } & \multicolumn{3}{c}{ Egg samples } \\
\cline { 2 - 4 } Moisture, \% & O_11 & O_22 & O_33 \\
Protein, g & 77.5 & 76.3 & 77.3 \\
Fat, g & 12.3 & 12.4 & 11.3 \\
- saturated (SAFA), g & 8.73 & 9.66 & 9.62 \\
- monounsaturated (MUFA), g & 4.5 & 2.7 & 2.7 \\
- polyunsaturated (PUFA), g & 1.7 & 1.8 & 5.2 \\
- $\omega 3$, g & 0.3 & 0.3 & 1.6 \\
- $\alpha$-linolenic acid, mg & 200 & 200 & 200 \\
- eicosapentaenoic acid, mg & $<100$ & $<100$ & $<100$ \\
- docosahexaenoic acid, mg & 100 & 100 & 100 \\
- $\omega 6$, g & 1.3 & 1.5 & 1.3 \\
- $\omega 6: \omega 3$ ratio & $4.3: 1$ & $5: 1$ & $4.3: 1$ \\
- $\omega 9$, g & 4.1 & 4.6 & 4.7 \\
Trans fatty acids, g & $<0.1$ & $<0.1$ & $<0.1$ \\
Cholesterol content, mg & $290^{\mathrm{ab} *}$ & $360^{\mathrm{a}}$ & $220^{\mathrm{b}}$ \\
Ash, g & 0.84 & 0.86 & 0.88 \\
Carbohydrates, g & $0.6^{\mathrm{a}}$ & $0.8^{\mathrm{ab}}$ & $0.9^{\mathrm{b}}$ \\
- sugars, g & $<0.2$ & $<0.2$ & $<0.2$ \\
Energy value, kJ & 541 & 583 & 563 \\
\hline vaw within the sam & &
\end{tabular}

*values within the same row sharing the same letter are not significantly different $(\mathrm{p}>0.05)$

The ratio of $\omega 6: \omega 3$ in food products has become fairly important when discussing the prevention of chronic diseases in humans. While previous research suggests that $\omega 6: \omega 3$ ratio of $4: 1$ is optimum for healthy adults, latest data indicates ratio of $2: 1$ to $1: 1$ as the target for human nutrition (Bhardwaj et al., 2016). This ratio falls just above the previous recommendations in free-range, barn and caged hens' eggs $(4.3: 1$ to $5: 1)$. Taking into account that most Western dietary patterns provide the ratio of $15: 1$ up to $25: 1$ (Bhardwaj et al., 2016), this is nonetheless a significant decrease and eggs should be included in a healthy diet as a source of essential fats.

The $\omega 6: \omega 3$ ratio in eggs from caged hens is significantly lower compared to other studies, where it varied from 11.03 : 1 to 66.29: 1 (Petrović et al., 2012; Lešić et al., 2017).

Insignificant differences were observed for the rest of the tested nutritional parameters (Table 4). Miranda et al. (2015) have reported similar nutritional parameters previously.

Vitamin content in eggs showed differences among samples (Table 5). Free-range eggs contained significantly lower amounts of vitamin A and E, yet more vitamin $D$ and folic acid $(p<0.05)$ than other samples. Lowest thiamine content was found in barn eggs $(\mathrm{p}<0.05)$ and eggs from caged hens had the least amount of folic acid $(\mathrm{p}<0.05)$.
Table 5

Vitamin content in eggs from different hen housing systems per $100 \mathrm{~g}$

\begin{tabular}{llll}
\hline \multirow{2}{*}{ Vitamins } & \multicolumn{3}{c}{ Egg samples } \\
\cline { 2 - 4 } & \multicolumn{1}{c}{ O_11 } & \multicolumn{1}{c}{ O_22 } & \multicolumn{1}{c}{ O_33 } \\
\hline $\mathrm{A}, \mu \mathrm{g}$ & $140.00^{\mathrm{a}^{*}}$ & $163.00^{\mathrm{b}}$ & $160.00^{\mathrm{b}}$ \\
$\mathrm{E}, \mathrm{mg}$ & $2.600^{\mathrm{a}}$ & $3.80^{\mathrm{b}}$ & $3.30^{\mathrm{b}}$ \\
$\mathrm{D}, \mu \mathrm{g}$ & $0.77^{\mathrm{a}}$ & $0.48^{\mathrm{b}}$ & $0.46^{\mathrm{b}}$ \\
$\mathrm{B}_{1}, \mathrm{mg}$ & $0.081^{\mathrm{a}}$ & $0.064^{\mathrm{b}}$ & $0.090^{\mathrm{a}}$ \\
$\mathrm{B}_{2}, \mathrm{mg}$ & 0.51 & 0.44 & 0.44 \\
$\mathrm{~B}_{3}, \mathrm{mg}$ & 0.20 & 0.20 & 0.10 \\
$\mathrm{~B}_{6}, \mu \mathrm{g}$ & 0.10 & 0.08 & 0.10 \\
$\mathrm{~B}_{12}, \mu \mathrm{g}$ & $0.067^{\mathrm{a}}$ & $0.087^{\mathrm{b}}$ & $0.075^{\mathrm{ab}}$ \\
$\mathrm{B}_{9}, \mu \mathrm{g}$ & $15.40^{\mathrm{a}}$ & $12.30^{\mathrm{b}}$ & $10.40^{\mathrm{c}}$ \\
$\mathrm{B}_{7}, \mu \mathrm{g}$ & $4.62^{\mathrm{a}}$ & $3.88^{\mathrm{b}}$ & $3.58^{\mathrm{b}}$ \\
\hline *
\end{tabular}

${ }^{*}$ values within the same row sharing the same letter are not significantly different $(\mathrm{p}>0.05)$

A study on vitamin content in egg yolk oil extracted from eggs obtained from different laying hen housing systems in Latvia (Kovalcuks, 2015) showed that free-range egg yolk oil contained significantly lower amounts of vitamin $\mathrm{E}$ ( $\mathrm{p}<0.05)$ compared to caged hens' egg yolk oil, which is in agreement with the current results. Content of vitamin A was not affected by the housing system, yet especially low content on vitamin $\mathrm{E}$ was found in eggs of free-range hens with free diet (no supplementation).

The findings of Anderson (2013) showed differences in eggs from caged hens compared to the results of this study - higher level of cholesterol (330 mg), which is closer to barn eggs in this research, significantly less vitamin A $(106.8 \mu \mathrm{g})$ compared to all tested samples, more vitamin E ( $4.8 \mathrm{mg}$ ), while content and composition of fatty acids was similar.

It has been reported that that free-range eggs contain more vitamin $\mathrm{E}$ and long chain $\omega 3$ fatty acids (Karsten et al., 2010), whereas eggs from caged hens have a lower fat content and less mono- and polyunsaturated fats than free-range eggs and barn eggs (Anderson, 2011). These data do not coincide with the results of eggs in Latvia; however, this could be explained by seasonal differences or genetics of hens (Küçükyilmaz et al., 2012). In addition, Karsten et al. (2010) reported that pastured free-range hens should be supplemented by commercial feed to meet optimal energy and protein needs.

Free-range eggs contained significantly more iodine than other egg samples $(p<0.05)$ (Table 6). The highest iron content was observed in barn eggs $(p<0.05)$, whereas the lowest copper, selenium and zinc levels were detected in eggs from caged hens $(p<0.05)$.

Research from Thailand showed that iodine content in regular eggs was $75.96 \mu$ g per 100 gram and in eggs enriched with iodine - around $184 \mu \mathrm{g}$ per 100 grams (Charoensiriwatana et al., 2014), while enriched eggs from Poland could accumulate up to $203 \mu \mathrm{g}$ iodine per 100 grams (Lipiec et al., 2012). 
Table 6

Content of minerals and heavy metals in eggs from different hen housing systems

\begin{tabular}{|c|c|c|c|}
\hline \multirow{2}{*}{ Parameters } & \multicolumn{3}{|c|}{ Egg samples } \\
\hline & O_11 & O_22 & O_33 \\
\hline $\mathrm{Na}, \mathrm{mg} 100 \mathrm{~g}^{-1}$ & 170.00 & 160.00 & 160.00 \\
\hline $\mathrm{K}, \mathrm{mg} 100 \mathrm{~g}^{-1}$ & 134.00 & 127.00 & 137.00 \\
\hline $\mathrm{Ca}, \mathrm{mg} 100 \mathrm{~g}^{-1}$ & $45.20^{\mathrm{a}^{*}}$ & $53.40^{\mathrm{b}}$ & $42.00^{\mathrm{a}}$ \\
\hline $\mathrm{Mg}, \mathrm{mg} 100 \mathrm{~g}^{-1}$ & $12.80^{\mathrm{a}}$ & $12.60^{\mathrm{a}}$ & $10.40^{\mathrm{b}}$ \\
\hline $\mathrm{P}, \mathrm{mg} 100 \mathrm{~g}^{-1}$ & 177.00 & 183.00 & 178.00 \\
\hline $\mathrm{Fe}, \mathrm{mg} 100 \mathrm{~g}^{-1}$ & $1.52^{\mathrm{a}}$ & $1.73^{\mathrm{b}}$ & $1.45^{\mathrm{a}}$ \\
\hline $\mathrm{Cu}, \mu \mathrm{g} 100 \mathrm{~g}^{-1}$ & $50.70^{\mathrm{a}}$ & $54.00^{\mathrm{a}}$ & $40.10^{\mathrm{b}}$ \\
\hline $\mathrm{Zn}, \mathrm{mg} 100 \mathrm{~g}^{-1}$ & $1.00^{\mathrm{ab}}$ & $1.10^{\mathrm{a}}$ & $0.84^{b}$ \\
\hline $\mathrm{Cl}^{-}, \%$ & 0.30 & 0.30 & 0.30 \\
\hline Se, $\mu \mathrm{g} 100 \mathrm{~g}^{-1}$ & $34.40^{\mathrm{a}}$ & $32.2^{\mathrm{ab}}$ & $30.30^{\mathrm{b}}$ \\
\hline $\mathrm{I}, \mathrm{mg} \mathrm{kg}^{-1}$ & $1.26^{\mathrm{a}}$ & $<0.50^{\mathrm{b}}$ & $<0.50 \mathrm{~b}$ \\
\hline $\mathrm{Pb}, \mathrm{mg} \mathrm{kg}^{-1}$ & $<0.010$ & $<0.010$ & $<0.010$ \\
\hline $\mathrm{Cd}, \mathrm{mg} \mathrm{kg}^{-1}$ & $<0.0010$ & $<0.0010$ & $<0.0010$ \\
\hline
\end{tabular}

*values within the same row sharing the same letter are not significantly different $(\mathrm{p}>0.05)$

Attia et al. (2017) analysed mineral content in eggs from caged hens; the comparison shows that eggs in Latvia have a higher content of magnesium, iron, lower content of sodium and phosphorus and equal content of zinc, potassium and copper. Whereas the content of calcium, iron and zinc was higher in hen eggs from Kenya (Chepkemoi et al., 2017).

Kiczorowska et al. (2015) reported that free-range system hens produced eggs richest in micronutrients $(\mathrm{K}$, $\mathrm{Na}, \mathrm{Ca}, \mathrm{Mg}, \mathrm{Zn}, \mathrm{Se}, \mathrm{Mn}$ and $\mathrm{Fe}$ ), as it allows hens to supplement their dietary ration. It is in partial agreement with our results.

Content of lead and cadmium in all egg samples was below the detection level, therefore, it can be concluded that all egg samples are free of heavy metals. A research of Egyptian scientists (Abdel-Hameid et al., 2017) established equally noticeable contamination with $\mathrm{Pb}$ and $\mathrm{Cd}$ in both free-range and caged hens' eggs.

In addition, the count of mesophilic aerobic and facultative anaerobic microorganisms and Enterobacteriaceae was below 10 colony forming units per gram, leading to conclusion that all egg samples are safe from microbiological point of view.

Eligibility of free-range, barn and caged hens' eggs to nutrient claims

Comparison of the amount of various nutrients to population reference intakes of vitamins and minerals (Table 3) allowed to evaluate the adherence of egg samples to nutrient claims (Table 2). Possible nutrient claims were quite similar for egg samples, yet there were several differences within various parameters (Table 7). All egg samples can be labelled as 'high protein', 'high omega-3 fatty acids' and 'high monounsaturated fat'. Free-range, barn and caged hens' eggs are eligible for such nutrient claims - "source of vitamin A", "source of phosphorus", "high vitamin $\mathrm{B}_{2}$ " and "high selenium" content. While free-range and caged hens' eggs are a "source of vitamin E", packaging of barn eggs can be labelled "high vitamin E".

Table 7

Compliance with requirements for nutrient content claims (EC No 1169/2011)

\begin{tabular}{|c|c|c|c|}
\hline \multirow{2}{*}{$\begin{array}{l}\text { Macro or micro } \\
\text { nutrient }\end{array}$} & \multicolumn{3}{|c|}{ Egg samples } \\
\hline & O_11 & O_22 & O_33 \\
\hline Protein* & $38 \%$ & $35 \%$ & $33 \%$ \\
\hline MUFA $^{\times}$ & $41 \%$ & $46 \%$ & $47 \%$ \\
\hline MUFA* & $31 \%$ & $33 \%$ & $35 \%$ \\
\hline$\omega 3(\mathrm{EPA}+\mathrm{DHA})$ & $>100 \mathrm{mg}$ & $>100 \mathrm{mg}$ & $>100 \mathrm{mg}$ \\
\hline Vitamin $A^{\infty}$ & $18 \%$ & $20 \%$ & $20 \%$ \\
\hline Vitamin $E^{\infty}$ & $22 \%$ & $32 \%$ & $28 \%$ \\
\hline Vitamin $\mathrm{D}^{\infty}$ & $15 \%$ & $10 \%$ & $9 \%$ \\
\hline Vitamin $\mathrm{B}_{1}^{\infty}$ & $7 \%$ & $6 \%$ & $8 \%$ \\
\hline Vitamin $\mathrm{B}_{2}{ }^{\infty}$ & $36 \%$ & $31 \%$ & $31 \%$ \\
\hline Vitamin $\mathrm{B}_{3}{ }^{\infty}$ & $1 \%$ & $1 \%$ & $1 \%$ \\
\hline Vitamin $\mathrm{B}_{6}{ }^{\infty}$ & $7 \%$ & $6 \%$ & $7 \%$ \\
\hline Vitamin $\mathrm{B}_{12}{ }^{\infty}$ & $3 \%$ & $3 \%$ & $3 \%$ \\
\hline Vitamin $\mathrm{B}_{9}^{\infty}$ & $8 \%$ & $6 \%$ & $5 \%$ \\
\hline Vitamin $\mathrm{B}_{7^{\infty}}$ & $9 \%$ & $8 \%$ & $7 \%$ \\
\hline Potassium $^{\infty}$ & $7 \%$ & $6 \%$ & $7 \%$ \\
\hline Calcium $^{\infty}$ & $6 \%$ & $7 \%$ & $5 \%$ \\
\hline Magnesium $^{\infty}$ & $3 \%$ & $3 \%$ & $3 \%$ \\
\hline Phosphorus $^{\infty}$ & $25 \%$ & $26 \%$ & $25 \%$ \\
\hline $\operatorname{Iron}^{\infty}$ & $11 \%$ & $12 \%$ & $10 \%$ \\
\hline Copper $^{\infty}$ & $5 \%$ & $5 \%$ & $4 \%$ \\
\hline $\operatorname{Zinc}^{\infty}$ & $10 \%$ & $11 \%$ & $8 \%$ \\
\hline Selenium $^{\infty}$ & $63 \%$ & $59 \%$ & $55 \%$ \\
\hline Iodine $e^{\infty}$ & $84 \%$ & $>30 \%$ & $>30 \%$ \\
\hline
\end{tabular}

* as \% of energy

$\times$ as $\%$ of fatty acids

${ }^{\infty}$ as $\%$ of nutrient reference (Table 3 ) supplied by $100 \mathrm{~g}$

Free-range eggs are also eligible for "source of vitamin D" and "high iodine". Barn and caged hens" eggs are a 'source of iodine'.

Coverage of vitamins and minerals in comparison to reference intakes in Latvia

According to the data of the Latvian Central Statistical Bureau (CSB), the daily consumption in Latvia was 207 eggs per capita in 2016; people consume ca. $1 / 2$ of egg daily on average. This does not, however, include bottled egg whites, egg powder, eggs added to pancakes, cake dough, salad with mayonnaise etc. (CSB, 2016).

Tested eggs cover various amounts of vitamins for Latvian consumers (Figure 1). Coverage of vitamin D, thiamine $\left(\mathrm{B}_{1}\right)$, pyridoxine $\left(\mathrm{B}_{6}\right)$, cyanocobalamin $\left(\mathrm{B}_{12}\right)$ and folic acid $\left(\mathrm{B}_{9}\right)$ for both males and females of an average egg (53 g) falls below 5\% daily, therefore, have an insignificant effect on diet. Coverage of vitamin A accounts up to $12 \%$ depending on gender. The highest coverage can be observed for vitamin E (17-25\% for females, $14-20 \%$ for males) and riboflavin (16-18\%). The differences observed in vitamin content of eggs (Table 5) does not a priori indicate that it will have a 
significant effect on the daily diet, based on vitamin coverage calculation (Figure 1).

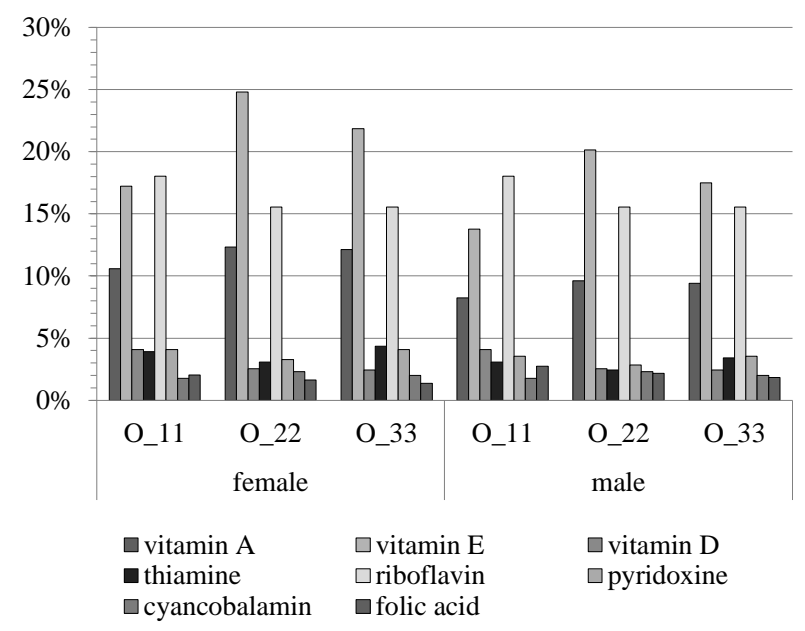

Figure 1. Coverage of vitamins $(\%)$ of an average egg $(53 \mathrm{~g})$ in comparison to reference intakes

O_11 - free-range eggs, O_22 - barn eggs, O_33 - eggs from caged hens

With regards to coverage of minerals (Figure 2), one average egg can provide below $5 \%$ of potassium, calcium, magnesium and cooper daily needs, whereas iron and zinc coverage is below $10 \%$.

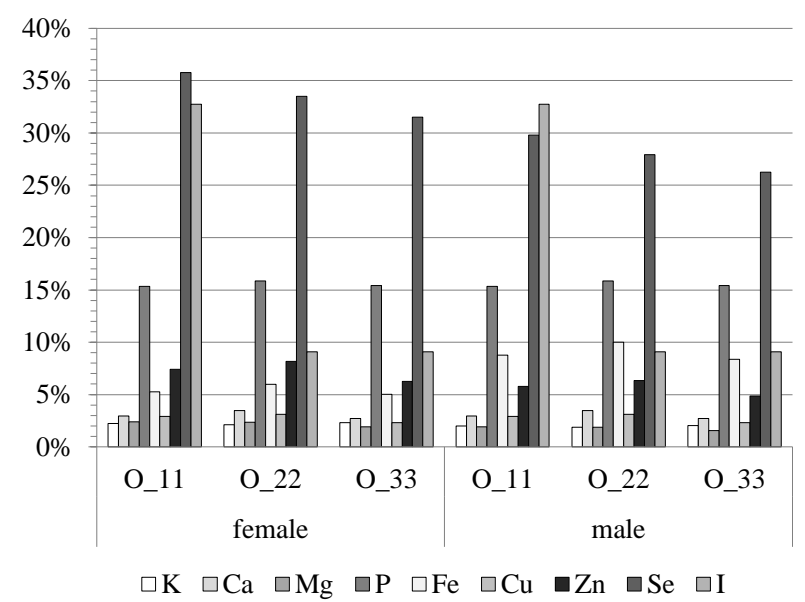

Figure 2. Coverage of minerals $(\%)$ of an average egg (53 g) in comparison to reference intakes

O_11 - free-range eggs, O_22 - barn eggs, O_33 - eggs from caged hens

Coverage of selenium ranges from 26 to $30 \%$ for males and 32 to $36 \%$ for females, which also does not indicate significant coverage differences.

Iodine is the only micronutrient that shows significant preference to consuming free-range eggs, as an average egg covers $33 \%$ of daily needs for Latvian adults. According to Konrāde et al. (2017), Latvian consumers, especially women, have insufficient iodine intake which could lead to brain development issues of foetus. It is suggested to increase daily iodine intake from seafood and milk products for women of childbearing age, and use iodine supplements during pregnancy.

Free-range eggs are 'high iodine', therefore, these eggs are also an excellent option to increase iodine content in daily diet.

\section{Conclusions}

The results indicate that different hen housing systems have an influence on egg nutritional composition in Latvia $(\mathrm{p}<0.05)$. Eggs are an excellent source of nutrients as shown by such nutrient claims - "high protein", "high omega-3 fatty acids", "high monounsaturated fat", "source of vitamin A", "source of vitamin E"/"high vitamin E", "high vitamin B2", "high selenium", "source of phosphorus", "source of vitamin D" and "source of iodine"/"high iodine". However, whether consumers choose free-range, barn and caged hens' eggs has an insignificant effect on their diet, based on daily egg consumption per capita.

These results also show the need for qualitative analyses of food produced in Latvia, as climatic conditions, soil and other factors indicate significant differences compared to other countries. In addition, further research is needed, in order to exclude seasonal effect on egg nutritional parameters.

\section{References}

1. Ahmed Abdel-Hameid A., Enas El-Prince M., Doha Y., Al-Shimaa M.F. (2017) Lead, cadmium and copper levels in table eggs. Journal of Advanced Veterinary Research, Vol. 7(3), p. 66-70.

2. Anderson K. E. (2011) Comparison of fatty acid, cholesterol, and vitamin A and E composition in eggs from hens housed in conventional cage and range production facilities. Poultry Science, Vol. 90(7), p. $1600-1608$

3. Anderson K. E. (2013) Comparison of fatty acid, cholesterol, vitamin A and E composition, and trans fats in eggs from brown and white egg strains that were molted or nonmolted. Poultry Science, Vol. 92(12), p. 3259-3265.

4. Attia Y.A., Mohammed A. Al-Harthi M.A., Shiboob M.M. (2014) Evaluation of Quality and Nutrient Contents of Table Eggs from Different Sources in the Retail Market. Italian Journal of Animal Science, Vol. 13(2), p. 369-376.

5. Benito-Vicente A., Uribe K.B., Jebari S., GaliciaGarcia U., Ostolaza H., Martin C. (2018) Familial hypercholesterolemia: The most frequent cholesterol metabolism disorder caused disease. International Journal of Molecular Sciences, Vol. 19(11), p. 3426.

6. Bhardwaj K., Verma N., Trivedi R.K., Bhardwaj S., Shukla N. (2016) Significance of ratio of omega-3 and omega-6 in human health with special reference to flaxseed oil. International Journal of Biological Chemistry, Vol. 10, p. 1-6.

7. Charoensiriwatana W., Srijantr P., Teeyapant P., Wongvilairattana J. (2014) Consuming iodine enriched eggs to solve the iodine deficiency endemic for remote areas in Thailand. In: Functional Foods. The Connection Between Nutrition, Health, and Food Science. L. Coles (ed.). Alberta: Apple Academic Press, p.279-288. 
8. Chepkemoi M., Macharia J.W., Sila D., Oyier P., Malaki P., Ndiema E., Agwanda B., Obanda V., Ngeiywa K.J., Lichoti J., Ommeh S.C. (2017) Physical characteristics and nutritional composition of meat and eggs of five poultry species in Kenya. Livestock Research for Rural Development, Vol. 29(8), p. 1-11.

9. Commission Regulation (EC) No 589/2008 of 23 June 2008 laying down detailed rules for implementing Council Regulation (EC) No 1234/2007 as regards marketing standards for eggs (OJ L 163, 24.6.2008, p. 6-23.

10. Commission Regulation (EU) No $116 / 2010$ of 9 February 2010 amending Regulation (EC) No 1924/2006 of the European Parliament and of the Council with regard to the list of nutrition claims (OJ L 37/16, 10.2.2010, p.16-18)

11. Coorey R., Novinda A., Williams H., Jayasena V. (2015) Omega-3 fatty acid profile of eggs from laying hens fed diets supplemented with chia, fish oil, and flaxseed. Journal of Food Science, Vol. 80(1), p. 180-187.

12. CSB Statistics Database (2013) Consumption of food products average per household member per year. [accessed on 10.01.2019.]. Available at: http://data.csb.gov.lv/.

13. Food and Agriculture Organization of the United Nations (FAO) (2003) FAO Food and Nutrition Paper No 77. Food energy - methods of analysis and conversion factors: Report of a technical workshop. Food and agriculture organization of the United Nations, Rome, p. 93.

14. Karcher D. M., Jones D. R., Abdo Z., Zhao Y., Shepherd T. A., Xin H. (2015) Impact of commercial housing systems and nutrient and energy intake on laying hen performance and egg quality parameters. Poultry Science, Vol. 94(3), p. 485-501.

15. Karsten H.D., Patterson P.H., Stout R., Crews G. (2010) Vitamins A, E and fatty acid composition of the eggs of caged hens and pastured hens. Renewable Agriculture and Food Systems, Vol. 25(1), p. 45-54.

16. Kiczorowska B., Smolinsky W., Kwiecień M., Winiarska-Mieczan A., Rusinek - Prystupa E., Ridha A., Al-Yasiry M. (2015) Nutritional value and the content of minerals in eggs produced in large-scale, courtyard and organic systems. Journal of Elementology, Vol. 20(4), p. 887-895.

17. Konrāde I., Kalere I., Strēle I., Makrecka-Kūka M., Veisa V., Gavars D., Rezeberga D., Pīrāgs D., Lejnieks A., Gruntmanis U., Neimane L., Liepiņš E., Dambrova M. (2017) Iodine deficiency in Latvia: current status and need for national recommendations. Proceedings of the Latvian Academy of Sciences. Section B, Vol. 71(6), p. 401-407.

18. Kovalcuks A. (2015) Comparison of bioactive compound content in egg yolk oil extracted from eggs obtained from different laying hen housing systems. International Journal of Biological, Food, Veterinary and Agricultural Engineering, Vol. 9(6), p. 589-593.

19. Kralik G., Kralik Z. (2017) Poultry products enriched with nutricines have beneficial effects on human health. Medicinski Glasnik, Vol. 14 (1), p. 1-7.
20. Küçükyılmaz K., Bozkurt, M., Herken, E.N., Çınar M., Çatl A.U., Bintaş E., Çöven F. (2012) Effects of rearing systems on performance, egg characteristics and immune response in two layer hen genotype. Asian-Australasian Journal of Animal Sciences, Vol. 25(4), p. 559-568.

21. Lešić T., Krešić G., Cvetnić L., Petrović M., Pleadin J. (2017) The influence of hen age on fatty acid composition of commercial eggs. Croatian Journal of Food Science and Technology, Vol. 9(2), p. 158-167.

22. Lipiec, E., Warowicka, O., Ruzik, L., Zhou Y., Jarosz M., Połeć-Pawlak K. (2012) Investigation of iodine bioavailability from chicken eggs versus iodized kitchen salt with in vitro method. European Food Research and Technology, Vol. 234(5), p. 913-919.

23. Miranda J.M, Anton X., Redondo-Valbuena C., RocaSaavedra P., Rodriguez J.A., Lamas A., Franco C.M., Cepeda A. (2015) Egg and Egg-Derived Foods: Effects on Human Health and Use as Functional Foods. Nutrients, Vol. 7(1), p. 706-729.

24. Nordic Nutrition Recommendations 2012. Integrating nutrition and physical activity. Nordic Council of Ministers, 2014. [accessed on 01.02.2019.]. Available at: https://norden.divaportal.org/smash/get/diva2:704251/FULLTEXT01.pdf

25. Petrović M., Gačić M., Karačić V., Gottstein Ž., Mazija H., Medić H. (2012) Enrichment of eggs in n-3 polyunsaturated fatty acids by feeding hens with different amount of linseed oil in diet. Food Chemistry, Vol. 135, p. $1563-1568$

26. Recommended allowance of energy and nutrition for Latvian citizens, ordinance No 212. Ministry of Health of the Republic of Latvia, November 24, 2017. [accessed on 01.02.2019.]. Available at: http://www.vm.gov.lv/images/userfiles/Tava\%20veselib a/Ieteicam\%C4\%81s_ener\%C4\%A3ijas_un_uzturvielu_ devas.pdf

27. Regulation (EC) No 1924/2006 of the European Parliament and of the Council of 20 December 2006 on nutrition and health claims made on foods (OJ L 404, 30.12.2006, p. 9)

28. Regulation (EU) No 1169/2011 of the European Parliament and of the Council of 25 October 2011 on the provision of food information to consumers, amending Regulations (EC) No 1924/2006 and (EC) No 1925/2006 of the European Parliament and of the Council, and repealing Commission Directive 87/250/EEC, Council Directive 90/496/EEC, Commission Directive 1999/10/EC, Directive 2000/13/EC of the European Parliament and of the Council, Commission Directives 2002/67/EC and 2008/5/EC and Commission Regulation (EC) No 608/2004 (OJ L 304, 22.11.2011, p. 18-63)

29. Sokołowicz Z., Krawczyk J., Dykiel M. (2008) Hen housing system and egg quality as viewed by consumers. Annals of Animal Science, Vol. 8(1), p. 71-80. 